At the present writing the eyes lave been well for two months, $\mathrm{O}$. $\mathrm{D}$. $\mathrm{V}=\frac{6}{6} ? \mathrm{O}$. S. $\mathrm{V}=\stackrel{\mathrm{i}}{\mathrm{i}}$.

I am fully aware of the small value to be attached to a single case regarding the action of any drug, but this one has, nevertheless, seemed of sufficient importance to be plaeed on record. In two cases of chronic iridocyclitis I have used the duboisia without any increased tension following, but atropia has been used in a great number of similar cases without producing jll results.

From the foregoing the following eonclusions seem justifiable.

1. That in solutions not stronger than two graius to the ounce duboisia sulphate is free from danger.

2. That the two-grain solution of duboisia sulphate more rapidly paralyzes the ciliary muscle than a four-grain solution of atropia sulphate.

3. That the duration of its effect is less than laalf that of atropia sulphate.

4. That the preparations now in the market are more liable to irritate the conjunctiva than neutral solutions of the sulphate of atropia.

5. 'That in the treatment of inflammations of the eye duboisia is quite as useful as atropial, and may therefore be used as a substitute.

In concluding this paper I desire to express my obligations to Dr. Gordon MI. Christoni for his careful aid in selecting from my case-book and tabulating the cases corrected under duboisia.

\title{
AnTici.l: XI.
}

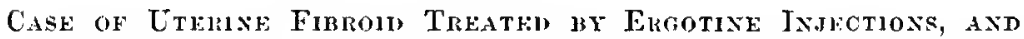

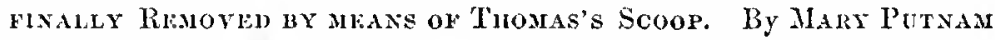
$J_{A C O B 1}$, M.1., of New York.

Mis. S., ret. 42, mother of nine children, of which the youngest is eight ycars old, consulted me on .July 3d for menorrhagia and metrorrhagia of five years'standing. Intense anamia had been developed in consedpuence of the repeated and prolonged liemorrhages, and the skin of the patient bad a subicteric tint, which from time to time deepened to a real jiundice lue. She was subject to attacks of aphonia, which, singularly enongh, did not coincide with periods of liemorrhage, but alternated with them; the roice being regained as soon as the flow set in. For this aphonia, eren more singularly, the patient had received, during six months, local treatment of the larynx at the clinic of a specialist.

A year before consulting me, Mrs. S. liad been sent to the clinic of an eminent gynæcologist, and, als far as I could understand from her report, the hemorrhage had been ascribed to granulations, which were then removed. After this, she was better for a little while, but all symptoms soon returned, and at the time of consulting me, nterine hemorrhage had been going on for a montl, and still persisted. It was unattended by pain.

Physical examination of the uterus disclosed two principal facts. 'The uterus, which was entirely in place, was, to bimanual palpation, consider- 
ably cnlarged, while the sound only penetrated to the deptli of eight centimetres. No irrcgularities of outline were discoverable in the uterus, either externally or internally. The cavity was molerately dilated. The dull wire curette passed over the fundus of the cavity, ocensioncd considerable bleeding, but removed no distinet granulations. 'The blecding was arrested by swabbing with nitrie acid diluted with equal parts of water.

On the 10 th of July I saw Mrs. S. again. The hemorrhage had not rcturned, and she was feeling better, but harl lost the use of her voicc, so that she could scarcely speak abore a whisper. She received a prescliption of ergot and gallic acid for the mcustrual periods, and I lost sight of her again until the 20 th of October. At this clatc the results of the examination were cxactly the same. The internal administration of ergot had had some, but not a very marked, effect upon the menorrhagia, but there had been no intermenstrual hemorrhage. It was evident that the diagnosis lay betwecn a simple liypertropliy of the womb and a mural fibroid, with much greater probability of the latter, on account of the shallow depth of the eavity as compared with the evident enlargement of the uterine walls. I proposed the alministration of ergotine liypodermically, and to this the patient comsented.

Between the 20 th and the 27 th, six lyypodermic injections werc given, encli containing one grain of crgotine dissolved in four minims of glycerine, four minims of water, and one minin of carbolic acid. The first three injections caused no pain, and very little local induration. With the fonrth, the patient began to lare uterine cramps, which lasted for an hour or two after tle injections. The local indurations causet by the injections were also very painful. On the 29 th the serentl injection was given, and after that the patient did not return until the 8 th of November. During this interval she menstruated, but the flow lasted only four days, and was not too profuse. During its eontinuance she had taken twenty grains of gallic acid every three hours. Feeling much encouraged by this diminution of the menorrhagia, she submitted to the eighth injection, and reccived two more thring the course of the following weck. The pains consequent upon these injections became always more severc, and on the 15 th, two or three days after the last injection, flowing returned, accompanied by a spontaneous acecss of pain. This lasted for three days, was expulsive in eharacter, and so violent that the attendant physician could only control it by lyppodermic injections of morphia. Finally, on the afternoon of the $18 \mathrm{th}$, the patient "felt something slip down in her belly;" at the same moment the pains abated and the hemorrliage ceased. Summoned in haste, the attending plysician diseovered a tumour projecting from the cervix uteri, and at once recognized that it had been forced down by means of the crgot. I saw the patient on the $22 \mathrm{~d}$. I then found a timour projecting from the cervix, whose inferior extremity was the size of a turkey egg. The finger eould easily bc swept all round the tumour between it and the cervix, but the pedicle conld not be reached. The fundus of the uterns was not depressed. The visible surface of the tumour was partly vascular, bleeding on tonch; partly covered with spots of superficial gangrene. A sanious diseharge oozed constantly from the uterus.

On the next day I removed tlic tumour, with the assistance of Dr. Krohlpfeiffer, the attending physician, Drs. Bopp, Stratss, Gunckin, and Cushier. As soon as the patient was etherized, it was ensy to draw down the tumour, and to invert the uterus sufficiently to bring the tumour almost 
entirely outside of the rulva. By means of Thomas's seoop, I then, in a few minutes, and without the slightitest diffieulty, cut through the base of the tumour, less than an inch below its point of attachment to the fundus uteri. The tumour was almost regularly ovoid in shape, so that its base was very nearly as broad as the inierior free extremity. But the base was composed of sueh dense, non-vaseular tissue that absolutely no bleeding took place after the section, and only a trifling oozing after the replacement of the uterus.

The tumour measured seven and a lalf inehes in its longer eireumference, and six and a half in its shorter. As already stated, a portion of the free extremity was smperfieially vasenlar, and the remainder was covered with green spots formerl by siperficial gangrene of the mucous membrane. On making a longitudinal seetion on the left of the tumour, extending upwards from the rascularized portion of the free extremity, a strip of caremons tissue was fomml, composed of large sinuses filled with dark congula. 'These sent projections into smaller simuses. This vascular' strip) was one-rfuarter of an inch broarl, and extended to within one inch of the base. Its dejth from the surface measmed one-half of an inch. Below the elot, the tissue was uniformly white, and composed of fibrous bands, which formed a coursely retieulated tissne.

'Thece longitudinal sections were made ou the posterior aspect of the tumour. The section the furthest to the right passed, at almost its mildle, throngh a ring, one-quarter of an inch in diameter, of rascular sinuses filled with darts red coacnla. The serend settion exhibited only two or three minute points of eoagulum. The third planged, at the depth of halt an inch below the surfice, into a group of largely tilated sinuses filled witl coagula. All these sinuses were lined by a smootl, transparent endothelium, demonstrated to be such by treatment, in the fresl state, with nitrate of silver.

Thus everywhere the bloodvessels, or rather blood sinuses, were found on the surface and towards the free extremity of the tumour. The base and the eentre were bloolless. The ressels did not rum from the base to the free extremity, but the reverse. They must, therefore, have been developer from the inucous surface, in other words, from the vascular layer of the endometrium, and not from the sinuses of the uterine wall. This derelopment into sinuses was in aceordanee with the general tendency to imitate the nterine type of structure which characterizes nterine fibroids. Mural fibroids are often deseribed as developed in the fibrous stroma of the uterine parenchyma, and becoming submucous, sessile, or peduneulated, by growing towards the uterine cavity. I3ut the arrangement of bloodvessels deseribed in our ease would imply that the tumour began in the embryonic cells lying under the endometrinm, and whieh are normally destined to furnish material for the menstrual deeidua. The cavity alpeared to be normal in length (eiglit eentimetres), until the tumour began to descend from the fundus.

The tumour, therefore, lad not grown from above downwards, but from

1 See the paper entitled "Memhranous Dysmenorrhcea," by Drs. George and Frances Hoggan, in Arch. für Gyuzk., Bd. x. 
below upwarls. Successive layers of new tissuc must have been constantly pushed npwards towards the fundus of the uterus, as still more layers developed in the enbryonic stratum under the endometrium. Thus, the zone of proliferation would have been intermediate to the two cxtremities, analogous to the zone of growth lying between the diaphysis and epiphysis of bones. On this account the base, being almost the oldest portion of the tumour, was, therefore, the least vascular: anatomical fact, explaining the apparently anomalous facility with which could be remored, without hemorrhage, a tumour whose surface had been bleeding profusely for five years.

Microscopic examination confirmed the inferences drawn from the disposition of the bloodvessels.

The surface of the tumour was found to consist of a condensed network of fibres, generally non-nnclcated. Immediately below the surfice, the fibres were infiltrated with small round cells. Below this, in various parts of the surface of the tumour, was found a strip of microscopically cavernous tissue, composed of a very coarse reticulum of fibres, whose meshes were filled with extravasated bloorl. Below this strip of liemorrhagic effusion was a band of muscular fibres, arranged in parallel and concentric layers, moderately infiltrated with embryonic cells, which became more abundant in the deeper part of the surface section, until, at its deepest, they almost entirely replaced all fibrons tissue, and formed a zone exclusively cellular. This zone could be traced entirely around the surface of the tumour, at the deptl of from one-eiglith to one-fourth of an inch from the mucous surface. Sections taken below this zone, i.e., towards the centre of the tumour, were evcrywhere composed of

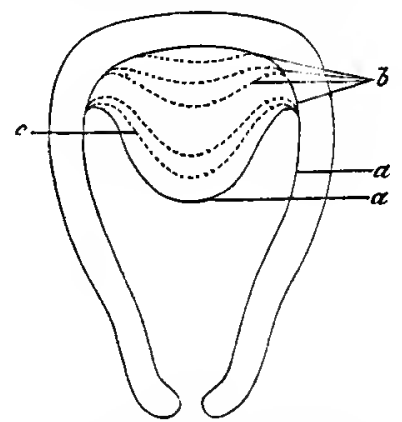

Schematic, $a, a$, Mincous surface of tumour, continuons with mucous anr. face of uterine cavity, $\partial$, Germinal luyers of cells, successively offuced duriug grow thof tumour and formation of stroma. c. Lastgerminal layer, persisting at time of removal of tamour. bands of nuclegted muscular fibres intersecting cach other at various angles, intermingled with patches of young conjunctive tissuc, or witl bands of matnre conjunctive fibres. At the centre of the tumour the tissue was most coarsely fibrous, forming bands visible to the naked eye. Throughout this muscrlar fibrous tissue, ccils were sparingly disseminatel, almost disappearing from scctions taken at or ncar the centre. Sections taken from the base of the tumour exhibited the same musculo-fibrons stroma and sparsc development of cells. The latter portions showed only two or three minute bloodvesscls, provided with muscular coats.

Thus, the microscopic examination showed that the germinal tissuc of the tumour was excrywhere near the surfacc, accompanying the bloodvessels, whosc surface distribution was visible to the naked eye, while the tissue below this germinal zone, constituting both the core and the base of the tumour, consisted of mature and non-vascular stroma.

The above diagram may serve to roughly represent the theory of the 
development of the tumour, which we have dedueed from the details of its strueture as above deseribed. The theory differs essentially from that which attributes the development of uterine fibroids to irritation of the muscular fibres of the uterine wall, and which describes the peduncle of polypi as bearing the blood ressels from the wall into the tumour. According to this theory, the musenlar fibre in the peduncle gradually atrophies and the vessels are obliterated.' According to the theory we have advanced, the non-vasenlarity of the pedmele or base is due to the fact that this part is the furtlest removed from the mueous membrane in whose vessels the bloodvessels of the tumour originate. This theory of development in the germinal eells lying underneath the endometrium eonld not apply to such tumours as are completely imbedded in and surrounded by uterine parenclyma, nor which develop under the peritoneun.'

The expulsion of the tumour was effected by a process precisely analogous to that of parturition. The eervix was thinned, and dilated at the expense of its lengtl, the fundus being spread ont and flattened down npon the tumour-following it without inversion, as it would follow an orum. On the day after the operation, the cavity of the uterus measured two and five-eighth inches, sensibly the same as before the removal of the tumour, but the walls seemed somewhat hypertrophied. Carbolized intra-uterine injections were made twiee a day for a week, and the patient recovered without the least rise of temperature or other bad symptom.

\section{Article XII.}

Cage of Fxtrexpye Traumatic Ixjury of the Skcla, Abscess of tile Brain, Right Hemplega, Apilasia, Recovery. By A. Limbig Elcan, M.D., of Covington, Tenn.

Arrir 14, 1878, I was ealled to see Claude $B$-, aged 5 years, soon after lie lad received an injury upon the hear, caused by a hcrse jawing him with his forefoot. I found him in an insensible condition, breathing slow and laboured, pupils contracted, pulse soft and eompressible, though

${ }^{1}$ Virehow, Die Krankhafte Gesehwulste._Cohnstein Frauenkrankheiten, pp. 122124. Beigel, Frauenkrankheiten, p. 405.

"It will be of course noticed that, in the ahove deseription, no distinction is made between the so-called "capsnle" and the tumour proper, according to the description commonly given-the tissues extending one-eighth to one-fourth of an inch from the surface, and including the ellular zone, would be referred to the capsule, composed of transformed mucous membrane that had becn pushed before the tumour during its outward growth. I lave not deserihed this capsule because the unbiassed examination of the entire neoplasm in successive sections, as above described, suggested the view stated in the text; namely, that the growth began in cmbryonic cells belonging to the inclosed tissue, and thence proceeded inwards. 